\title{
DAMPAK LIBERALISASI PERDAGANGAN TERHADAP KINERJA INDUSTRI MANUFAKTUR DI INDONESIA (PENDEKATAN STRUCTURE-CONDUCT-PERFORMANCE)
}

\author{
Hendy Aprilian Hidayat \\ Fakultas Ekonomika dan Bisnis, Universitas Diponegoro \\ hendyaprilianhidayat@gmail.com \\ Alfa Farah \\ Fakultas Ekonomika dan Bisnis, Universitas Diponegoro \\ alfafarah@undip.ac.id
}

\begin{abstract}
The influx of imported goods in the domestic market will pressure domestic producers to be more efficient. The more effiecient the domestic firm, the more competitive it becomes. This competitive firm is expected to have opportunities to expand to a larger market. This study analyzed the effect of trade liberalization to industrial performance in Indonesia. This study exploited data at the industry level, ie: 38 industries of three digits International Standard Industrial Classification (ISIC) during 2000-2009. The analysis was conducted within Structure Conduct Performance (SCP) framework. Industrial performance was measured by price-costmargin and trade liberalization was measured by export share and a dummy indicating implementation of Asean Free Trade Area (AFTA). Using the fixed effect model, the result showed weak evidence of the effect of trade liberalization to industrial performance in Indonesia. Dummy AFTA was negative and significant to industrial performance while export share was insignificant. The results might indicate that the adoption of AFTA endangered domestic firms' performance.
\end{abstract}

Keywords: trade, liberalization, industrial performance, 3 digits ISIC

\section{PENDAHULUAN}

Sejak tahun 1980-an, Indonesia telah mengadopsi kebijakan liberalisasi perdagangan secara komprehensif. Hal ini dibuktikan dengan partisipasi dan inisiasi Pemerintah Indonesia untuk mengikuti berbagai kerjasama unilateral untuk menderegulasi rezim perdagangan dan investasi sebagai respon terhadap penurunan harga minyak (Pangestu 2002). Penerbitan Undang-Undang No. 7 Tahun 1994 tentang ratifikasi "Agreement Establishing the World Trade Organization" menjadikan Indonesia secara resmi menjadi anggota World Trade Organization (WTO). 
Dengan demikian, sejak 1995 semua persetujuan yang ada di dalam WTO telah sah menjadi bagian dari legislasi nasional.

Salah satu implikasi dari keikutsertaan Indonesia dalam WTO adalah, pengurangan tarif perdagangan produk industri manufaktur. Pada masa awal keanggotaan Indonesia di WTO, dari 7.536 produk industri yang diikat tarifnya, sebanyak 6.848 pos tarif diikat pada tingkat 40 persen dan 688 pos tarif diikat pada tingkat kurang dari 40 persen. Selain itu, hambatan nontarif atas 98 pos tarif serta bea masuk tambahan atas 172 pos tarif dihapuskan dalam jangka waktu sepuluh tahun (Departemen Perindustrian dan Perdagangan 1994).

Menurut data Departemen Keuangan, bea masuk rata-rata di Indonesia telah turun hingga menjadi 7,81 persen pada 2007. Padahal pada awal 1995, ketika WTO mulai aktif berlaku menjadi legislasi nasional, rata-rata tarif di Indonesia adalah sebesar 15,48 persen. Penurunan tarif ini sesuai dengan Surat Keputusan Menteri Keuangan Nomor 378/KMK.01/1996 tentang jadwal penurunan tarif di Indonesia. Selain berdasarkan surat keputusan menteri tersebut, penurunan tarif disesuaikan dengan undang-undang kepabeanan serta komitmen Indonesia di bidang tarif dengan WTO, Asia-Pacific Economic Cooperation (APEC), ASEAN Free Trade Area (AFTA) dan perjanjian-perjanjian lain yang telah disepakati.

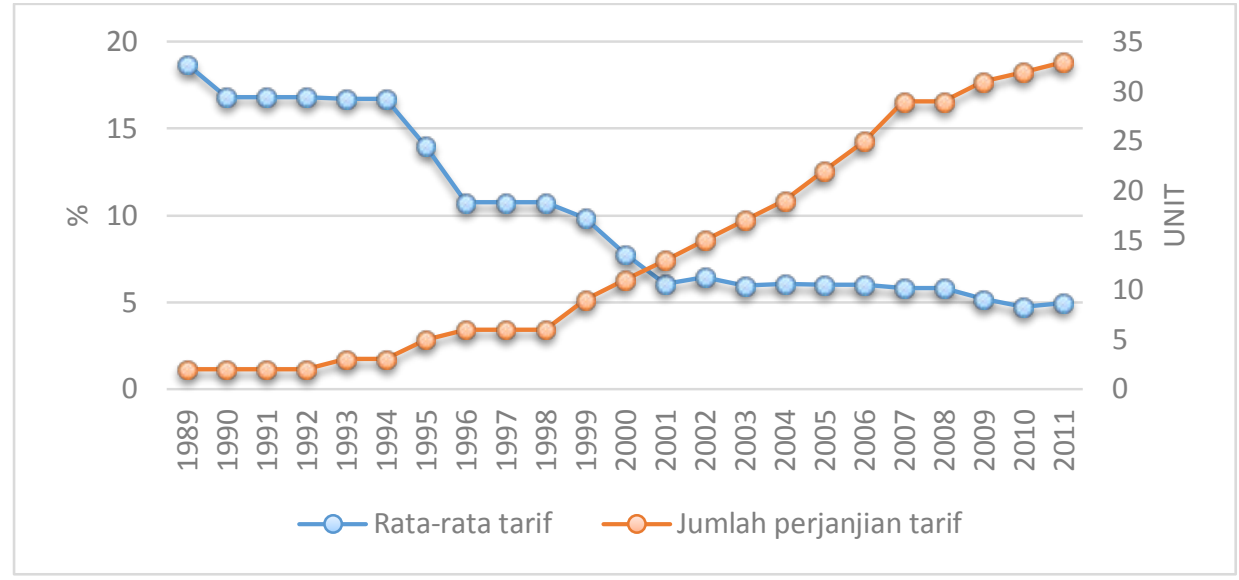

Sumber data: UNCTAD

\section{Gambar 1 \\ Tarif dan Jumlah Perjanjian Tarif Indonesia}

Selain menyetujui perjanjian multilateral, Indonesia juga aktif menurunkan hambatan perdagangan dengan menyetujui perjanjian perdagangan bilateral dan regional. Dalam formasi AFTA, keinginan politik yang kuat mendorong pemerintah Indonesia untuk mempercepat pemberlakuan AFTA dari tahun 2008 menjadi tahun 2002 (aktif pada 2003). Indonesia juga telah menyetujui perjanjian penurunan tarif dalam kerangka Asean-China Free Trade Agreement (ACFTA), serta perjanjian bilateral dengan India, Korea, Jepang, Selandia Baru dan Australia. Berbagai 
kesepakatan yang diikuti Indonesia membuktikan komitmen Pemerintah Indonesia untuk mereformasi rezim perdagangan menjadi lebih terbuka.

Berbagai perjanjian perdagangan bebas yang disepakati Indonesia menyebabkan menurunnya tarif. Gambar 1 memperlihatkan penurunan tarif rata-rata (simple average tariff) dan jumlah perjanjian perdagangan yang disepakati Indonesia. Berdasarkan data United Nations Conference on Trade and Development (UNCTAD), tarif rata-rata untuk semua produk di Indonesia turun dari sekitar 19 persen pada 1989 menjadi sekitar lima persen pada 2011. Hal tersebut merupakan implikasi dari terus meningkatnya jumlah perjanjian tarif yang disepakati Indonesia, dari tiga perjanjian pada tahun 1989 menjadi sekitar 33 perjanjian pada tahun 2011.

Penurunan tarif diikuti oleh peningkatan jumlah pos tarif. Jika dilihat dari Gambar 2, penurunan tarif rata-rata diiringi oleh peningkatan jumlah pos tarif, berarti semakin banyak komoditas yang mengalami penurunan tarif. Hal ini dikonfirmasi dengan penurunan tingkat proteksi pada level industri. Menurut perhitungan Widodo (2008), penurunan tarif telah terjadi di semua sektor industri manufaktur.

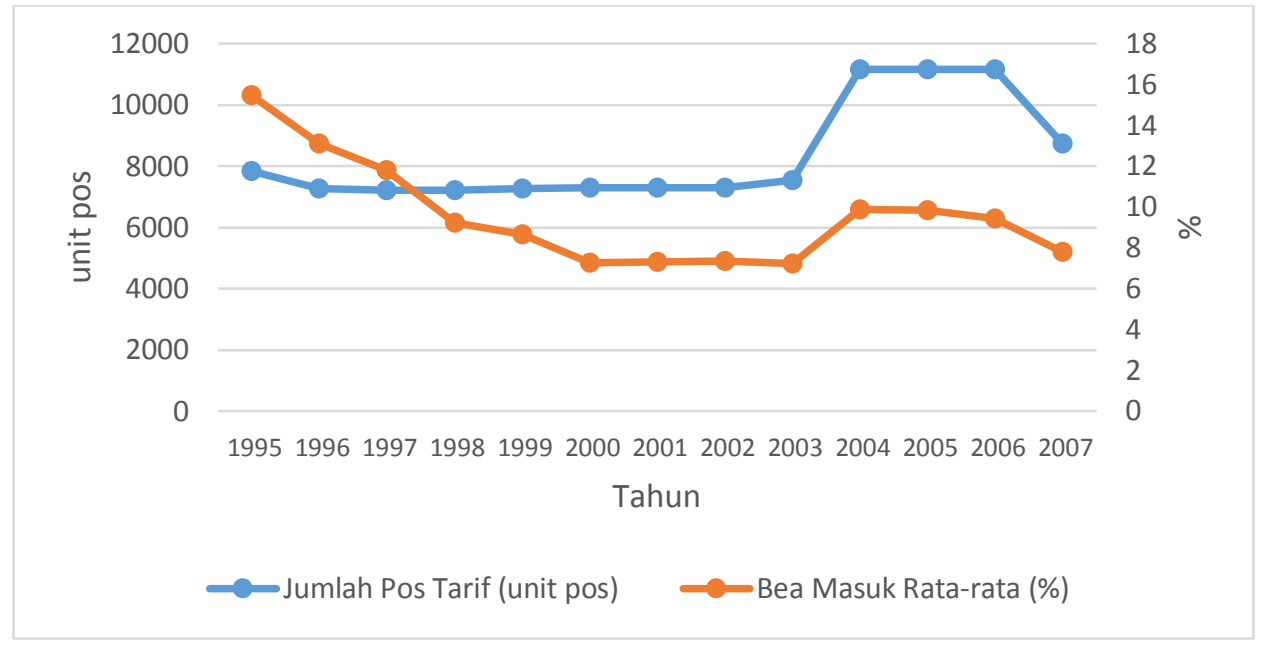

Sumber: Departemen Keuangan

\section{Gambar 2}

Jumlah Pos dan Tingkat Tarif Indonesia

Sektor industri manufaktur, sebagai penyokong terbesar dalam komposisi Gross Domestic Product (GDP) Indonesia, adalah salah satu sektor yang mendapatkan dampak terbesar dari liberalisasi perdagangan. Tarif sektor industri manufaktur secara umum menurun. Widodo (2008) melakukan perhitungan dan konversi tarif yang diberlakukan pada sektor industri manufaktur di Indonesia. Hasil perhitungan Widodo (2008) menunjukkan struktur tarif di berbagai industri di Indonesia terus menurun walaupun dengan besaran yang berbeda. Pada tahun 1991 rata-rata tarif untuk semua produk industri manufaktur di Indonesia adalah 20,88 persen. Setelah Indonesia resmi menjadi anggota WTO pada tahun 1995, struktur tarif turun menjadi 15,6 persen. Pada tahun 2005 tarif telah jauh menurun menjadi 
hanya sekitar 5,8 persen. Industri tekstil (kode 32), kayu (kode 33) dan logam (kode 36) merupakan industri yang mengalami penurunan tarif paling signifikan.

Tabel 1

Tingkat Proteksi Efektif (dalam persen)

\begin{tabular}{|c|c|c|c|c|c|c|c|}
\hline \multirow{2}{*}{$\begin{array}{c}\text { IO } \\
\text { Code }\end{array}$} & \multirow{2}{*}{ Industry } & \multicolumn{4}{|c|}{ Indonesia } & \multirow{2}{*}{$\begin{array}{c}\text { Malaysia } \\
2003\end{array}$} & \multirow{2}{*}{$\begin{array}{c}\text { Vietnam } \\
2003\end{array}$} \\
\hline & & 1991 & 1995 & 2001 & 2005 & & \\
\hline 27 & Food manufacture industry & 18,8 & 65,5 & 49,6 & 29,4 & 3,6 & 43,9 \\
\hline 28 & Oil and fat industry & 48 & 59,5 & 38,7 & 12,3 & 5,8 & 18,5 \\
\hline 29 & Rice milling industry & 178 & 117,5 & 82,9 & 17,8 & 11,4 & 123,2 \\
\hline 30 & Flour industry & 57,8 & 61,6 & 31,9 & 10,2 & 11,4 & 34 \\
\hline 31 & Sugar industry & 26,1 & 45,7 & 58,6 & 11,7 & 3,8 & 34 \\
\hline 32 & Other food industry & 48,7 & 56,8 & 35,9 & 11,7 & 3,8 & 34 \\
\hline 33 & Beverage industry & 43,8 & 51,2 & 25,7 & 15,3 & 24,3 & 55,4 \\
\hline 34 & Tobacco industry & 37,5 & 35,7 & 23,3 & 14,5 & 5,3 & 55,3 \\
\hline 35 & Knitting industry & 63,7 & 49,3 & 17,3 & 13,5 & 13,9 & 71 \\
\hline 36 & $\begin{array}{l}\text { Textile, clothes and leather } \\
\text { industry }\end{array}$ & 94,2 & 61 & 17,7 & 13,9 & 28,6 & 43 \\
\hline 37 & Bamboo, wood and rattan industry & 53,4 & 53,2 & 16 & 10,7 & 21 & 1,2 \\
\hline 38 & $\begin{array}{l}\text { Paper, paper product and carton } \\
\text { industry }\end{array}$ & 49,4 & 25,4 & 6,6 & 4 & 7,8 & 17,1 \\
\hline 39 & Fertilizer and pesticide industry & 54,4 & 40,6 & 16,5 & 11,5 & 4,1 & $-1,7$ \\
\hline 40 & Chemical industry & 46,9 & 34,8 & 12 & 7,9 & 1,6 & -4 \\
\hline 41 & Refined petroleum industry & 40,7 & 27,5 & 11,3 & 7,8 & 4,1 & - \\
\hline 42 & $\begin{array}{l}\text { Rubber and plastic products } \\
\text { industry }\end{array}$ & 59,5 & 40,9 & 13 & 9,7 & 17,5 & 21,8 \\
\hline 43 & Non-metallic mineral products & 34,1 & 26,9 & 12,2 & 8,6 & 15,8 & 47,8 \\
\hline 44 & Cement industry & 52,3 & 30,6 & 16,8 & 11,5 & 7,2 & 49,7 \\
\hline 45 & Iron and steel industry & 58,6 & 23,4 & 11,8 & 9,4 & 6,6 & $-20,9$ \\
\hline 46 & Non-ferrous metal industry & 74,4 & 35,3 & 15 & 9,1 & 18 & 0,8 \\
\hline 47 & Metallic products industry & 68,9 & 28,9 & 9,7 & 8,4 & 4,9 & - \\
\hline 48 & $\begin{array}{l}\text { Machinery and electrics equipment } \\
\text { industry }\end{array}$ & 57,9 & 47,1 & 10,8 & 6,8 & 2,4 & 2 \\
\hline 49 & Transportation equipment industry & 30,8 & 20,1 & 8,6 & 7,7 & 21,7 & 46,6 \\
\hline 50 & Other manufacturing products & 74,9 & 56,2 & 19,6 & 15 & 4 & 34,6 \\
\hline & Maximum (Max.) & 178 & 117,5 & 82,9 & 29,4 & 28,6 & 123,2 \\
\hline & Minimum (Min.) & $-18,8$ & 20,1 & 6,6 & 4 & 1,6 & $-20,9$ \\
\hline & Range $=($ Max - Min $)$ & 196,8 & 97,4 & 76,3 & 25,4 & 27 & 144,1 \\
\hline & Simple Average & 55,6 & 45,6 & 23,4 & 11,6 & 10,4 & 32,2 \\
\hline
\end{tabular}

Sumber: Widodo (2008)

Dibandingkan dengan negara-negara tetangga, Indonesia memiliki laju liberalisasi perdagangan industri manufaktur yang relatif paling paling cepat. Tabel 1 menunjukkan bahwa laju penurunan tarif di Indonesia lebih cepat dibandingkan Vietnam, walaupun tidak secepat Malaysia. Rata-rata tingkat proteksi efektif industri-industri di Indonesia turun dari 55,6 pada tahun 1991 menjadi 11,6 persen pada 2005. 
Penurunan tarif yang berimbas pada kinerja industri manufaktur menandai fase ke-empat perkembangan sektor industri manufaktur Indonesia. Menurut Zanden (2012), setidaknya Indonesia mengalami empat fase perkembangan sektor industri manufaktur. Pertama adalah fase pertumbuhan yang sangat cepat, yakni pada periode tahun 1967-1973 sebagai dampak dari liberalisasi dan restorasi stabilitas makroekonomi. Fase ke-dua adalah fase inward looking dan substitusi impor yang merupakan implikasi dari peningkatan harga minyak pada tahun 1973. Kebijakan ini diikuti dengan pemberlakuan tarif dan hambatan nontarif. Penurunan harga minyak setelah tahun 1981 kemudian mendorong berjalannya fase ke-tiga, yakni penciptaan manajemen makroekonomi dan devaluasi mata uang. Fase ke-empat kebijakan industri ditunjukkan dengan liberalisasi perdagangan dan promosi sektor industri manufaktur dengan mengurangi hambatan tarif dan nontarif. Selain itu Indonesia juga meliberalisasi peraturan penanaman modal asing, serta mereformasi sektor keuangan untuk mengurangi kekuatan monopoli bisnis-bisnis besar. Perubahan rezim perdagangan tersebut diperlihatkan pada Gambar 3.

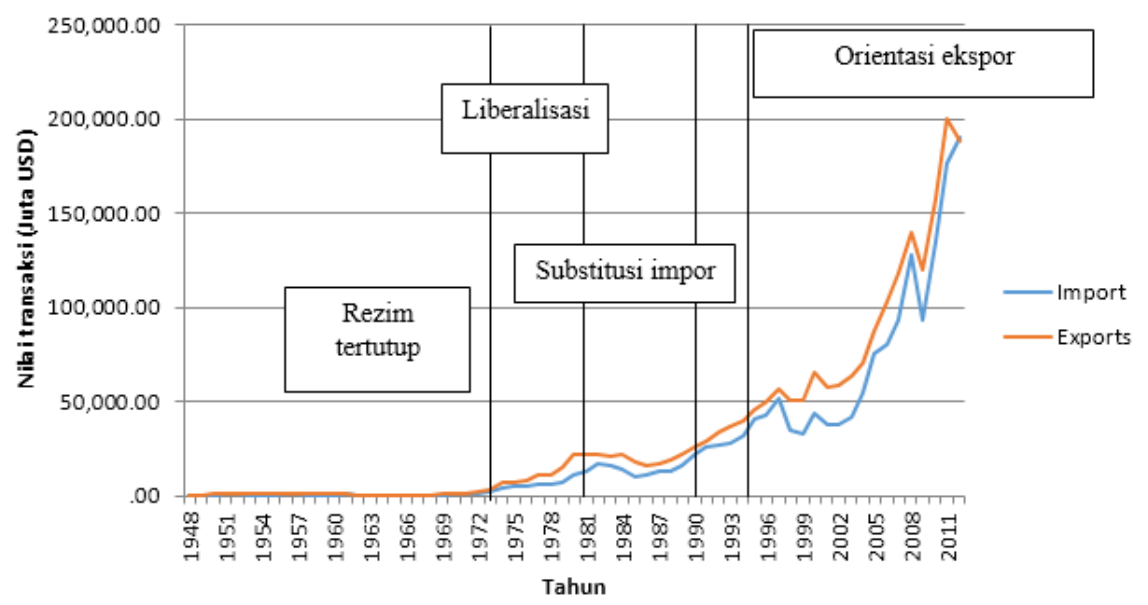

Sumber data: WTO

\section{Gambar 3}

Rezim Perdagangan dan Nilai Transaksi Perdagangan Indonesia

Berkurangnya tarif perdagangan diyakini akan memengaruhi kesejahteraan produsen. Di satu sisi, pengurangan hambatan perdagangan akan mengurangi surplus produsen dan jumlah produksi domestik. Penurunan surplus produsen dapat dimaknai sebagai berkurangnya kemampuan kemampuan produsen untuk mendapatkan keuntungan atas barang yang dijualnya. Akan tetapi di sisi yang lain, kesepakatan perdagangan internasional memberikan peluang bagi pengembangan sektor industri. Liberalisasi perdagangan yang disepakati oleh banyak negara akan membuka peluang meluasnya pasar produk-produk perusahaan domestik.

Meluasnya pasar produk-produk manufaktur Indonesia salah satunya dapat dilihat dari perubahan komposisi ekspor Indonesia. Pada awal 1975, ekspor 
Indonesia didominasi oleh hasil minyak. Hal ini didukung oleh tingginya harga minyak dunia (oil boom). Sejak diterapkannya kebijakan industrialisasi promosi ekspor pada awal tahun 1980an, persentase ekspor produk manufaktur terus meningkat, bahkan pada akhir tahun 1980an, produk industri manufaktur mendominasi komposisi komoditas ekspor. Gambar 4 menunjukkan perubahan komposisi ekspor Indonesia dari waktu ke waktu.

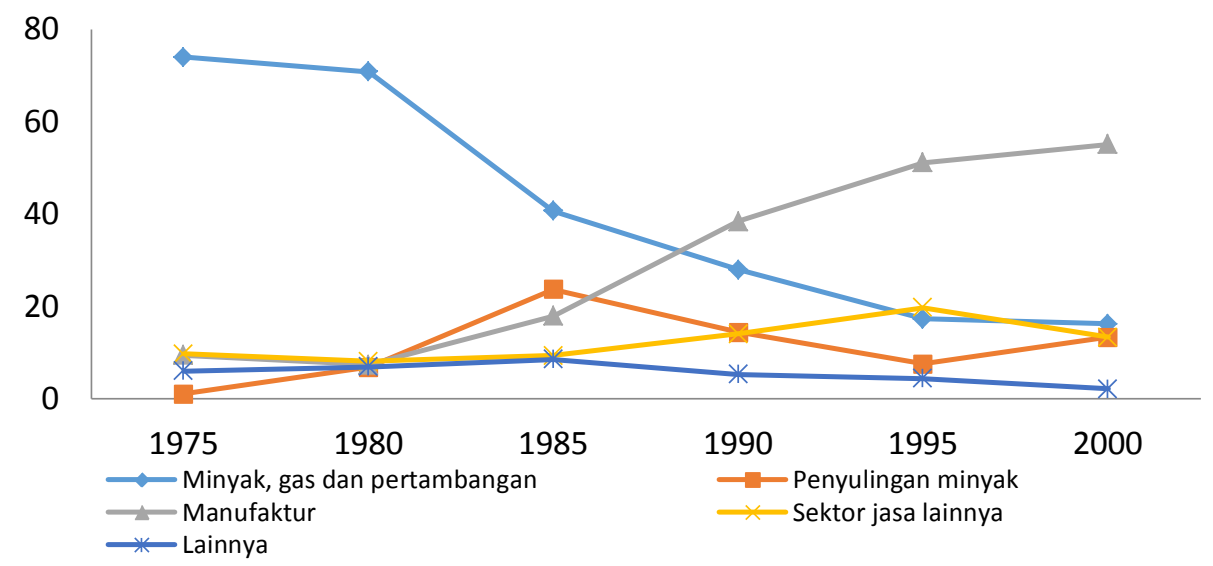

Sumber: Jacob dalam Zanden (2012)

Gambar 4

Komposisi Ekspor Indonesia

Pengaruh liberalisasi perdagangan terhadap kinerja perusahaan setidaknya dapat dilihat dari dua sisi, yaitu (1) pengaruh terhadap persaingan di dalam pasar domestik dan (2) insentif untuk berekspansi ke pasar yang lebih luas. Menurut Lipczinsky (2005), kebijakan liberalisasi perdagangan dapat memengaruhi struktur melalui pengurangan penguasaan pasar (market power). Rezim perdagangan bebas menyebabkan transaksi ekspor dan impor menjadi semakin intensif. Secara teoretis, arus barang impor dapat menyebabkan biaya rata-rata yang dihadapi perusahaan domestik menurun. Meningkatnya jumlah perusahaan serta produk dalam industri domestik menyebabkan biaya rata-rata setiap perusahaan menurun. Penurunan biaya rata-rata ini mendorong penurunan harga produk di pasar domestik. Penurunan harga tersebut secara teoretis dapat memengaruhi kinerja perusahaan dalam industri.

Liberalisasi perdagangan yang menyebabkan meningkatnya jumlah perusahaan di dalam sebuah industri, mendorong industri menjadi lebih kompetitif. Kinerja perusahaan dalam struktur industri yang kompetitif tentu berbeda dengan industri yang terkonsentrasi. Kinerja perusahaan salah satunya dapat dilihat dari tingkat profitabilitas. Dalam konteks liberalisasi perdagangan ukuran profitabilitas menunjukkan seberapa besar produsen domestik mampu memanfaatkan fenomena perdagangan bebas. Semakin besar kemampuan perusahaan menangkap peluang liberalisasi perdagangan, semakin besar profit yang mungkin didapatkan perusahaan di dalam industri. Sebaliknya, semakin tidak mampu perusahaan domestik untuk 
menghadapai tekanan produk impor dan semakin tidak mampu perusahaan domestik berekspansi keluar, semakin kecil profit yang mungkin didapatkan.

Liberalisasi perdagangan juga mendorong perusahaan domestik untuk berekspansi ke pasar dunia. Dengan tarif perdagangan yang lebih rendah serta hambatan perdagangan nontarif yang semakin minim, perusahaan domestik menghadapi pasar yang semakin luas. Pasar yang semakin luas tersebut merupakan peluang perusahaan untuk mendapatkan keuntungan lebih besar.

Pertanyaan yang ingin dijawab dalam peelitian ini adalah bagaimana pengaruh kebijakan liberalisasi perdagangan Indonesia terhadap kinerja industri manufaktur di Indonesia.

Selain diharapkan mampu memberikan sumbangan pemikiran untuk memperluas khazanah pengetahuan ilmu ekonomi, hasil penelitian ini dapat dijadikan gambaran dan acuan untuk merumuskan kebijakan yang lebih baik dalam rangka memanfaatkan fenomena liberalisasi perdagangan. Dengan begitu, produsen domestik dapat memanfaatkan peluang yang muncul dari semakin bebasnya perdagangan internasional.

\section{KAJIAN PUSTAKA DAN PENGEMBANGAN HIPOTESIS}

Hambatan perdagangan yang semakin rendah akan menyebabkan aliran barang impor dan ekspor meningkat sehingga diprediksi akan memengaruhi struktur industri domestik. Dalam kerangka Structure-Conduct-Performance (SCP), struktur pada akhirnya akan memengaruhi kinerja perusahaan di dalam industri. Oleh karena itu, liberalisasi perdagangan akan memengaruhi kinerja perusahaan di dalam industri melalui struktur pasar yang berubah menjadi semakin kompetitif.

Bhagwati (dalam Krugman 1986) menganalogikan perusahaan yang bersifat monopolis di pasar domestik (tetapi price taker di pasar dunia) dihadapkan dengan perusahaan asing yang tidak dapat menentukan harga (price taker). Menurut model Bhagwati, penurunan tarif mengurangi kekuatan monopoli perusaan domestik. Hal ini akan menyebabkan tertekannya profit perusahaan domestik.

Berlakunya increasing return to scale dalam perdagangan internasional menyebabkan terjadinya pasar persaingan tidak sempurna. Pada gilirannya, perusahaan yang memiliki skala hasil meningkat dan berproduksi efisien dapat menggusur perusahaan-perusahaan lain di dalam pasar sehingga industri akan diisi oleh beberapa perusahaan saja. Dalam pasar domestik, industri-industri yang tidak mampu bersaing dengan perusahaan asing akan keluar dari pasar. Menurut Promfet (1992), struktur pasar persaingan tidak sempurna pada perdagangan internasional didukung bukti dari struktur pasar sektor pertanian dan industri manufaktur yang cenderung oligopoli. 
Yalcin (2000) menyimpulkan bahwa dalam kerangka pasar persaingan tidak sempurna, liberalisasi perdagangan internasional mampu meningkatkan kesejahteraan negara yang menganutnya. Liberalisasi akan mengurangi distorsi yang terbentuk dalam struktur pasar persaingan tidak sempurna. Liberalisasi perdagangan juga akan memperluas pasar serta mengurangi biaya rata-rata dengan meningkatkan efisiensi spesialisasi pekerja dalam konteks diferensiasi produk.

Penelitian mengenai dampak liberalisasi perdagangan terhadap kinerja industri manufaktur telah dilakukan peneliti-peneliti sebelumnya. Ozcan et al. (2000) meneliti pola liberalisasi pedagangan dan konsentrasi industri di Turki. Estimasi Ozcan et al. (2000) menghasilkan kesimpulan bahwa reformasi kebijakan perdagangan yang lebih terbuka menghasilkan dampak yang kecil pada struktur industri. Derajat keterbukaan mempunyai pengaruh kecil pada konsentrasi, PriceCost Margin (PCM) dan perilaku investasi. Peneliti tersebut juga menyimpulkan bahwa marjin profit dipengaruhi oleh konsentrasi industri dan peningkatan tingkat upah riil.

Yalcin (2000) meneliti tentang dampak liberalisasi perdagangan dan struktur industri pada kinerja industri manufaktur di Turki. Dengan menggunakan analisis panel data dengan model Fixed Effect Model, Random Effect Model dan Two Stages Least Square (TSLS), penelitian ini mengestimasi data panel yang mencakup industri yang dikelompokkan dalam klasifikasi International Standard Industrial Classification (ISIC) empat digit. Penelitian tersebut membedakan antara dampak liberalisasi pedagangan pada industri di sektor publik dan swasta. Hasilnya, penetrasi impor yang meningkat sebagai implikasi dari liberalisasi pedagangan berpengaruh pada penurunan PCM pada industri di sektor swasta. Namun, PCM pada industri sektor swasta yang terkonsentrasi justru meningkat. Hal ini mengindikasikan adanya kolusi antara produsen dari luar negeri dan di dalam negeri. Sebaliknya, industri di sektor publik justru menurun pada industri yang terkonsentrasi sebagai hasil dari penetrasi impor dan ekspansi ekspor.

Jayanthakumaran (2002) melakukan telaah terhadap penelitian empiris mengenai dampak liberalisasi perdagangan terhadap kinerja industri manufaktur di negara berkembang. Meskipun menunjukkan gambaran terjadinya peningkatan ekspor dan output sektor industri manufaktur pasca liberalisasi perdagangan, Jayanthakumaran (2002) menjelaskan bahwa tidak ada bukti nyata yang menunjukkan bahwa liberalisasi perdagangan menyebabkan peningkatan ekspor dan output tersebut.

Goldar dan Aggarwal (2004) meneliti tentang dampak liberalisasi perdagangan pada kinerja industri di India. Penelitian ini juga menggunakan Fixed Effect Model (FEM) dan Random Effect Model (REM) untuk menganalisis data panel yang mencakup industri pada level tiga digit selama 1980-1997. Estimasi Goldar dan Aggarwal (2004) menghasilkan kesimpulan bahwa PCM pada industri di India justru 
tidak menurun setelah rezim perdagangan yang semakin terbuka. Bahkan PCM cenderung meningkat pada kelompok industri agregatif.

Penelitian dengan kasus Indonesia telah dilakukan oleh Astiyah et al. (2005). Astiyah et al. (2005) meneliti tentang dampak liberalisasi perdagangan terhadap perilaku harga di Indonesia. Penelitian tersebut menggunakan PCM sebagai indikator dari perilaku harga dan menyimpulkan bahwa liberalisasi perdagangan menghasilkan harga yang justru meningkat dan berpotensi meningkatkan inflasi.

Yoseva (2009) juga meneliti pengaruh liberalisasi terhadap kinerja industri domestik. Hasil penelitian menunjukkan liberalisasi perdagangan yang diukur dengan derajat keterbukaan memiliki pengaruh negatif pada kinerja industri domestik yang diukur dengan PCM. Penelitian Yoseva (2009) menjelaskan secara umum gap antara paradigma SCP dengan keadaan nyata bahwa perekonomian dunia saling berkaitan. Berbeda dengan itu, penelitian kali ini menjelaskan proses evolusi kebijakan perdagangan di Indonesia sebagai titik tolak analisis terhadap dampak liberalisasi perdagangan pada kinerja industri domestik.

Berbeda dengan penelitian-penelitian sebelumnya, penelitian ini menggunakan pangsa ekspor (export share) sebagai ukuran liberalisasi perdagangan. Meskipun merupakan ukuran yang kasar, pangsa ekspor dapat dijadikan acuan untuk melihat perilaku perusahaan-perusahaan di Indonesia dalam merespon kebijakan liberalisasi perdagangan. Dengan demikian, penelitian ini dapat menganalisis apakah perusahaan-perusahaan eksportir tersebut mampu meraih manfaat dari rezim perdagangan yang semakin terbuka.

Berdasarkan kerangka pemikiran dan analisis teori yang mendasari, maka hipotesis dalam penelitian ini adalah sebagai berikut.

H1: Liberalisasi perdagangan berpengaruh negatif terhadap kinerja industri manufaktur Indonesia.

\section{METODA PENELITIAN}

Model empiris dibangun untuk menjawab pertanyaan penelitian yang diajukan. Estimasi model dilakukan dengan menggunakan metode panel data Fixed Effect Model (FEM). Penelitian ini secara a priori menggunakan FEM dengan berdasarkan pada kesesuaian kelebihan dan kekurangan model dengan tujuan penelitian dan alasan teoritis. FEM pada dasarnya mengestimasi dengan mengizinkan individu (cross section) untuk memiliki intersepnya sendiri. Model ini memungkinkan analisis mengenai heterogenitas masing-masing individu dengan memberikan dummy untuk setiap individu. Penggunaan metode FEM diharapkan dapat memberikan gambaran perbedaan karakter masing-masing industri dalam menerima dampak liberalisasi perdagangan, namun bersifat tetap sepanjang waktu (time invariant). 
Model penelitian ini adalah sebagai berikut:

$P C M_{i t}=\beta_{0}+\beta_{1} \mathrm{EXS}_{i t}+\beta_{2} \mathrm{HHI}_{i t}+\beta_{3} \mathrm{LABPROD}_{i t}+\beta_{4} \mathrm{DAFTA}_{i}+\sum_{i=37} \beta_{5}$ DUM $_{i}+\mu \mathrm{it}$.

Dengan PCM adalah adalah kinerja perusahaan yang diukur dengan price-cost margins, HHI adalah struktur pasar yang diukur Herfindahl Hirschmann Index, EXS adalah liberalisasi perdagangan yang diukur dengan pangsa ekspor (export share). Sebagai pembanding dari HHI, Concentration Ratio (CR4) digunakan sebagai ukuran struktur pasar. Variabel dummy AFTA (DAFTA) juga digunakan untuk melihat apakah liberalisasi perdagangan memengaruhi kinerja industri. Disamping variabel-variabel tersebut, model juga mengikutsertakan variabel kontrol, yaitu produkstivitas tenaga kerja ( $L A B O R P R O D)$ adalah produktivitas tenaga kerja. Variabel DUM adalah dummy intersep, i adalah unit industri dan $t$ adalah tahun. Tanda yang diharapkan untuk masing-masing variabel adalah: EXS dan DAFTA bertanda negatif sedangkan $H H I$ dan $L A B O R P R O D$ bertanda positif.

Selain melihat pengaruh liberalisasi perdagangan terhadap kinerja industri manufaktur, penelitian ini juga ingin melihat apakah pengaruh liberalisasi perdagangan terhadap kinerja industri terjadi melalui jalur struktur industri. Oleh karena itu, estimasi juga akan dilakukan untuk melihat pengaruh liberalisasi perdagangan terhadap struktur industri dengan model sebagai berikut:

$H H I_{i t}=\beta_{0}+\beta_{1}$ EXS $_{i t}+\beta_{2}$ LABORPROD $_{i t}+\beta_{3}$ DAFTA $_{i}+\sum_{i=37} \beta_{4} D U M_{i}+\mu$ it

Penelitian ini menggunakan profitabilitas sebagai indikator dari kinerja perusahaan. Alat ukur yang dapat digunakan untuk menghitung profitabilitas adalah price-cost margins. Dalam penelitian ini, PCM dihitung dengan formula:

$P C M=\frac{\text { Output total-biaya total }}{\text { output total }}$

Liberalisasi perdagangan dalam penelitian ini diukur dengan pangsa ekspor. Ukuran pangsa ekspor sebagai indikator liberalisasi perdagangan memang merupakan indikator yang kasar. Namun, ukuran ini pada dasarnya cukup logis menggambarkan liberalisasi perdagangan. Yalcin (2000) mengusulkan penggunaan pangsa ekspor (export share) untuk mengukur tingkat keterbukaan sebuah industri. Analoginya adalah jika hambatan perdagangan internasional dikurangi atau dihilangkan, maka aliran ekspor dan impor barang industri akan semakin mudah. Nilai pangsa ekspor menggambarkan porsi ekspansi perusahaan domestik ke pasar dunia. Pangsa ekspor (EXS) dihitung dengan membandingkan jumlah barang yang diekspor (X) dengan total output $(Q)$ per kode industri, dengan formula sebagai berikut:

$E X S=\frac{X}{Q}$

Tingkat konsentrasi merupakan salah satu ukuran yang dapat digunakan untuk menentukan struktur industri. Penelitian ini menggunakan HerfindahlHirschmann Index (HHI) untuk mengukur tingkat konsentrasi. Selain HHI, penelitian 
ini juga menggunakan $C R 4$ sebagai pembanding. Rasio konsentrasi $(C R n)$ dihitung dengan membandingkan antara jumlah penjualan beberapa perusahaan terbesar dalam industri dengan total penjualan dalam industri tersebut.

$C R n=\frac{\text { Jumlah penjualan } \mathrm{n} \text { perusahaan terbesar }}{\text { Jumlah penjualan dalam industri }}$

Herfindahl-Hirschman Index dihitung dengan menjumlahkan pangkat dua dari pangsa pasar perusahaan di dalam industri, atau secara formal ditulis:

$H H I=\sum_{\mathrm{i}=\mathrm{I}}^{\mathrm{N}} \mathrm{S}_{\mathrm{i}}^{2}$

$\mathrm{S}_{\mathrm{i}}$ merupakan pangsa pasar dari perusahaan $\mathrm{i}$, dan $\mathrm{N}$ adalah total jumlah perusahaan di dalam industri. Nilai maksimum dari indeks $H H I$ adalah 1 dan nilai minimumnya adalah $1 / \mathrm{N}$. Industri yang didalamnya terdapat satu perusahaan monopoli mempunyai nilai $H H I$ sama dengan 1.

\section{Sampel dan Data Penelitian}

Jenis data yang digunakan dalam penelitian ini berupa data sekunder dalam bentuk time series dan cross section (panel data) dengan periode waktu tahunan. Data yang digunakan dalam penelitian ini adalah data rasio konsentrasi $(C R)$, nilai output, nilai input, nilai tambah, upah, nilai ekspor dan nilai impor dari tahun 2000 hingga tahun 2010.

Data yang digunakan dalam penelitian didapatkan dari publikasi BPS dan WTO. Untuk publikasi BPS yang digunakan adalah Statistik Industri Sedang dan Besar, serta Indikator Industri Sedang dan Besar. Data WTO yang digunakan adalah total ekspor dan impor. Industri yang digunakan pada penelitian ini adalah 38 industri manufaktur sedang dan besar dengan pengelompokan golongan International Standard Industrial Classification (ISIC) tiga digit dari 151 hingga 372. Pengelompokan ISIC yang digunakan adalah berdasarkan ISIC 2005.

\section{HASIL DAN PEMBAHASAN}

Kuncoro (2010) menyebutkan salah satu permasalahan sektor industri manufaktur di Indonesia adalah struktur industri yang belum dalam dan seimbang. Struktur industri di Indonesia cenderung monopolistik dan oligopoli. Hasil perhitungan juga menunjukkan tidak ada perubahan yang signifikan pada struktur industri manufaktur di Indonesia selama periode penelitian. Pada tahun 2000 ratarata $C R 4$ untuk total industri manufaktur adalah 0,47 sedangkan pada tahun 2010 nilai CR4 industri manufaktur di Indonesia adalah 0,42. Hal tersebut pada dasarnya mengindikasikan tidak adanya gejolak perekonomian yang dapat menyebabkan berubahnya struktur industri selama periode penelitian.

Tabel 2 menunjukkan deskripsi keadaan industri manufaktur Indonesia secara umum. Sebagaimana ditunjukkan Tabel 2 dan diperjelas oleh Kuncoro (2010), 
industri di Indonesia masih cenderung terkonsentrasi. Rata-rata CR4 untuk seluruh industri mencapai 0,43. Hal ini berarti sekitar 43 persen total industri dikuasai oleh 4 perusahaan terbesar. Nilai standar deviasi menunjukkan bahwa diantara CR4, HHI dan PCM, nilai CR4-lah yang paling beragam. Hal ini mengindikasikan pengikutsertaan perusahaan kecil (dalam $H H I$ ) memberikan pengaruh pada perhitungan konsentrasi industri.

Tabel 2

Statistik Deskriptif Industri Manufaktur di Indonesia (2000-2010)

\begin{tabular}{lcrrrr}
\hline Variabel & Obervasi & Rata-rata & Std. Deviasi & Min. & \multicolumn{1}{c}{ Maks. } \\
\hline EXS & 418 & 53,77 & 25,98 & 0,00 & 100,00 \\
CR4 & 418 & 0,43 & 0,22 & 0,07 & 1,00 \\
PCM & 418 & 0,39 & 0,11 & 0,05 & 0,66 \\
HHI & 418 & 0,10 & 0,12 & 0,01 & 0,81 \\
LABORPROD & 418 & $147.930,92$ & $165.490,75$ & $4.047,29$ & $1.107 .953,50$ \\
\hline
\end{tabular}

Sumber: BPS, diolah

Faktor perbedaan keadaan awal industri menyebabkan keberagaman CR4 masing-masing industri. Industri instrumen optik dan peralatan fotografi (kode 332) merupakan industri yang paling terkonsentrasi. Pada tahun 2003, CR4 industri tersebut mencapai 1 , artinya ada 4 perusahaan yang sangat dominan. Dalam periode penelitian, rata-rata $C R 4$ industri instrumen optik adalah 0,87. Hal ini sangat bertolak belakang dengan industri dengan industri pakaian jadi kecuali pakaian berbulu (kode 181). Industri tersebut memiliki rata-rata nilai $C R 4$ sebesar 0,11. Artinya empat perusahaan terbesar hanya menguasai sekitar 11 persen dari total output industri.

Tidak jauh berbeda dengan $C R 4$, nilai PCM industri manufaktur di Indonesia juga cenderung beragam. Nilai PCM untuk semua industri tidak mengalami perubahan yang signifikan selama tahun 2000 hingga 2001. Nilai PCM yang tertinggi adalah industri semen (kode 264). Industri semen memiliki rasio profit mencapai 0,66 pada tahun 2007 dengan nilai rata-rata selama periode penelitian mencapai 0,56 .

Hal menarik lain yang dapat dilihat dari Tabel 2 adalah perbedaan yang sangat jauh antara nilai maksimal dan minimal pangsa ekspor. Nilai maksimal pangsa ekspor industri di Indonesia adalah seratus persen sedangkan nilai minimalnya nol persen. Hal ini menunjukkan ada industri yang mengekspor semua hasil produksinya dan ada industri yang menjual semua hasil produksinya di dalam negeri. Industri kapuk (kode 174) merupakan salah satu industri yang menjual semua hasil produksinya di dalam negeri sedangkan industri optik dan alat fotografi (kode 332) pada tahun 2000 dan 2001 mengekspor semua hasil produksinya.

Sebelum hasil estimasi disajikan dan diinterpretasikan, deteksi normalitas residual dan pelanggaran asumsi klasik dilakukan. Hasil uji normalitas residual menunjukkan residual model terdistribusi normal. Deteksi multikolinearitas dan 
autokorelasi menunjukkan bahwa model tidak mengalami masalah multikolinearitas sempurna dan autokorelasi. Akan tetapi, terjadi permasalahan heteroskedastisitas, sehingga penelitian ini menggunakan White robust standard error atau disebut juga dengan White's heteroskedasticity-consistent variances and standard error. Hasil estimasi regresi dirangkum dalam Tabel 3.

Tabel 3

Hasil Estimasi Model Utama

\begin{tabular}{lcc}
\hline \multirow{2}{*}{ Variabel Independen } & \multicolumn{2}{c}{ Model utama } \\
\cline { 2 - 3 } C & Variabel dependen: PCM & Variabel dependen: PCM \\
HHI & 0.359 & 0.376 \\
& $(10.03)^{* * *}$ & $(10.498)^{* * *}$ \\
EXS & -0.084 & \\
& $(-1.396)^{* *}$ & \\
LABORPROD & -0.0003 & $-3.00 \mathrm{E}-04$ \\
& $(-0.957)$ & $(-0.998)$ \\
CR4 & $3.48 \mathrm{E}-07$ & $3.60 \mathrm{E}-07$ \\
& $(6.928)^{* * *}$ & $(7.052)^{* * *}$ \\
DAFTA & & 0.027 \\
& & $(0.662)$ \\
\hline R2 & -0.024 & -01.822900 .024 \\
R2 Adj. & $(-2.354)^{* *}$ & $(-2.36)^{* *}$ \\
F-stat & 0.493 & 0.496 \\
Durbin Watson & 0.433 & 0.437 \\
VIF & 8.264 & 8.347 \\
Sumber: perhitungan & 1.870283 & 1.823357 \\
& 1.972 & 1.984 \\
\hline
\end{tabular}

Sumber: perhitungan penulis

Keterangan: angka bercetak dan di dalam kurung merupakan nilai t statistik, nilai $\mathrm{t}$ telah disesuaikan dengan robust standar error, nilai alfa $10 \%$ *; nilai alfa $5 \% * *$; nilai alfa $1 \% * * *$.

Secara umum, hasil estimasi model utama menunjukkan EXS sebagai ukuran liberalisasi perdagangan bertanda negatif tetapi tidak siginifikan. Ini berarti pangsa ekspor tidak memengaruhi kinerja industri manufaktur di Indonesia. Sebaliknya, dummy AFTA signifikan memengaruhi kinerja industri domestik. Sesuai dengan hipotesis, dummy AFTA sebagai variabel liberalisasi perdagangan memiliki tanda negatif. Produktivitas tenaga kerja sebagai variabel kontrol menunjukkan pengaruh positif dan signifikan terhadap kinerja industri manufaktur.

Sesuai dengan hipotesis, $H H I$ bertanda negatif dan signifikan. Hal ini sesuai dengan hipotesis bahwa struktur memengaruhi kinerja berdasarkan paradigma SCP. Satu hal yang menarik, mengganti ukuran struktur pasar dengan CR4 memunculkan hasil yang berbeda. Tanda CR4 positif dan secara statistik tidak signifikan memengaruhi PCM.

Ukuran goodness of fit model dengan menggunakan adjusted $R^{2}$ adalah 0,49 persen. Ini berarti variabel-variabel independen pada model mampu menjelaskan 49 persen variabel PCM. Nilai F hitung yang lebih besar F tabel $(1,29)$ menunjukkan bahwa variabel independen secara simultan memengaruhi struktur industri. 
Hasil estimasi model tambahan menunjukkan tanda variabel liberalisasi perdagangan tidak sesuai dengan hipotesis baik menggunakan variabel dependen HHI maupun CR4. Akan tetapi karena hasil uji normalitas residual menunjukkan residual tidak terdistribusi normal maka model tambahan tidak akan dilakukan penarikan kesimpulan.

Tabel 4

Hasil Estimasi Model Tambahan

\begin{tabular}{lcc}
\hline \multirow{2}{*}{ Variabel Independen } & \multicolumn{2}{c}{ Model tambahan } \\
\cline { 2 - 3 } & Variabel dependen: CR4 & Variabel dependen: HHI \\
\hline$C$ & 0.54 & 0.12 \\
EXS & $(13.67)^{* * *}$ & $(4.25)^{* * *}$ \\
& 0.00054 & 0.00014 \\
LABORPROD & $(1.463)$ & $(0.56)$ \\
& $8.94 \mathrm{E}-08$ & $5.89 \mathrm{E}-08$ \\
DAFTA & $(1.603)^{* *}$ & $(1.52)^{* *}$ \\
& 0.002 & 0.00053 \\
\hline R2 & $(0.149)$ & $(0.05)$ \\
R2 Adj. & 0.75 & 0.57 \\
F-stat & 0.73 & 0.52 \\
Durbin Watson & 28.54 & 12.27 \\
VIF & 1.822900 & 1.831491 \\
\hline
\end{tabular}

Sumber: perhitungan penulis

Keterangan: angka bercetak dan di dalam kurung merupakan nilai t statistik, nilai telah disesuaikan dengan robust standar error, nilai alfa $10 \% *$; nilai alfa $5 \% * *$; nilai alfa $1 \% * * *$

Terdapat beberapa temuan yang menarik dari hasil estimasi model utama. Berbeda dengan hipotesis paradigma SCP, HHI sebagai variabel struktur secara signifikan memengaruhi variabel kinerja dengan tanda negatif. Menurut Kwoka (1985), tanda negatif pada variabel struktur seringkali ditemukan. Misalnya ada beberapa perusahaan dominan diikuti oleh perusahaan lain yang lebih banyak sedangkan perusahaan dominan sangat menguasai pasar. Ukuran HHI yang mengakomodasi pangsa pasar perusahaan kecil mengindikasikan bahwa perusahaan kecil mendapatkan profit yang semakin sedikit pada keadaan industri yang semakin terkonsentrasi.

Sesuai dengan hipotesis yang diajukan, liberalisasi perdagangan memiliki pengaruh yang negatif dan signifikan terhadap kinerja industri domestik. Variabel liberalisasi perdagangan yang memengaruhi kinerja secara signifikan adalah dummy kebijakan AFTA, sedangkan pangsa ekspor tidak. Secara umum, Jayanthakumaran (2002) memberikan penjelasan bahwa hubungan antara pangsa ekspor, konsentrasi dan kinerja industri berifat kompleks. Terdapat dua argumen yang berbeda yang menjelaskan hubungan pangsa ekspor pada kinerja industri domestik. Pertama, hubungan antara pangsa ekspor dan kinerja bersifat terbalik. Artinya kinerja perusahaan memengaruhi pangsa ekspor, bukan sebaliknya. Perusahaan domestik 
mengekspor barang karena kelebihan keuntungan yang yang diterima dari industri domestik. Perusahaan domestik yang memiliki produktivitas rendah cenderung kesulitan untuk menghadapi tekanan tekanan persaingan yang kuat dari pasar dunia. Oleh karena itu, hanya perusahaan yang memiliki keuntungan berlebih yang akan mengekspor barang. Argumen kedua adalah adanya hubungan positif antara pangsa ekspor dan kinerja industri domestik. Hal ini terjadi ketika eksportir hanya mengekspor barangnya jika mendapatkan keuntungan lebih besar daripada penjualan domestik.

Insignifikansi pangsa ekspor terhadap PCM mengindikasikan eksportir di Indonesia secara umum belum mampu meningkatkan pengambilan keuntungan dari kebijakan liberalisasi perdagangan. Jika dikaitkan dengan dua argumen yang dijelaskan Jayanthakumaran (2002), kondisi tersebut menunjukkan bahwa hubungan antara pangsa ekspor dan kinerja industri di Indonesia cenderung mengarah kepada argumen pertama. Perusahaan domestik mengalami tekanan yang kuat di pasar dunia. Keadaan seperti ini umumnya dihadapi oleh perusahaan-perusahaan di negara berkembang yang memiliki produktivitas relatif rendah sedangkan di pasar ekspor mereka harus bersaing dengan perusahaan dari negara maju. Oleh karena itu hanya perusahaan-perusahaan domestik yang telah memiliki keuntungan berlebih dan mampu berproduksi efisien yang menjadi eksportir.

Berbeda dengan pangsa ekspor yang mengukur liberalisasi perdagangan secara umum, penggunaan variabel dummy kebijakan AFTA signifikan memengaruhi kinerja industri di Indonesia dengan tanda negatif. Hal ini berarti diterapkannya kebijakan AFTA pada tahun 2003 justru mengurangi profit yang diterima perusahaan-perusahaan di Indonesia. Dengan kata lain, kebijakan AFTA berdampak negatif pada kinerja industri domestik. Effendi (2014) menjelaskan bahwa ekspor Indonesia masih under trade dengan semua negara ASEAN yang mengindikasikan rendahnya pemanfaatan AFTA. Padahal sejatinya AFTA merupakan implementasi dari keinginan kerjasama negara-negara di ASEAN dalam bidang ekonomi.

\section{SIMPULAN, KETERBATASAN DAN IMPLIKASI}

\section{Simpulan}

Liberalisasi perdagangan secara teoretis memengaruhi kinerja sektor industri manufaktur. Liberalisasi perdagangan membuka persaingan global untuk masuk melalui barang-barang impor dan peluang ekspansi ekspor. Penyatuan pasar menjadi satu pasar dunia dengan negara-negara yang semakin terintegrasi membuat pasar yang dihadapi perusahaan tidak hanya pasar domestik.

Hasil analisis menunjukkan liberalisasi perdagangan berpengaruh negatif

pada kinerja industri domestik. Pengaruh negatif liberalisasi perdagangan ditunjukkan dengan signifikannya variabel dummy AFTA. Hasil ini mengindikasikan 
bahwa kinerja industri manufaktur di Indonesia kesulitan untuk mendapatkan keuntungan dari semakin terbukanya perdagangan antarnegara ASEAN.

\section{Keterbatasan dan Saran}

Keterbatasan utama dalam penelitian ini adalah pada pengukuran liberalisasi perdagangan. Pengukuran liberalisasi perdagangan sejatinya lebih menekankan pada impor, bukan peluang ekspor. Hal ini karena penetrasi impor-lah yang akan memengaruhi struktur industri domestik. Kedua, keterbatasan data menyebabkan pengukuran PCM, CR4 dan HHI pada penelitian ini didasarkan pada data output (bukan data penjualan). Ketiga, industri yang dianalisis dalam penelitian ini adalah industri secara keseluruhan. Hal ini menyebabkan analisis atas strategi yang diterapkan perusahaan relatif bias dan bersifat indikatif.

Saran bagi peneliti selanjutnya yang ingin meneliti topik serupa adalah menggunakan indikator yang lebih menggambarkan keadaan liberalisasi perdagangan. Indikator yang dapat digunakan adalah derajat keterbukaan maupun penetrasi impor. Untuk itu, data impor per kode ISIC seharusnya mampu didapatkan.

\section{DAFTAR PUSTAKA}

Astiyah, S., A. R. Hutabarat, dan D. Sianipar. 2005. Dampak liberalisasi perdagangan terhadap perilaku pembentukan harga produk industri melalui structure-conduct performance model. Buletin Ekonomi Perbankan dan Moneter Vol.7 No.4. Jakarta: Bank Indonesia.

Badan Pusat Statistik. 2010a. Indikator Industri Besar dan Sedang 2000-2010. Badan Pusat Statistik: Jakarta.

, 2010b. Statistik Industri Besar dan Sedang 2000-2010. Badan Pusat Statistik: Jakarta.

Departemen Perindustrian dan Perdagangan Republik Indonesia. 1994. World Trade Organization Sebagai Lembaga Pelaksana dalam Mewujudkan Liberalisasi Perdagangan Dunia. Dalam daftar kerjasama Direktorat Jenderal Kerja Sama Perdagangan Internasional (KPI). Jakarta: Dirjen KPI.

Effendi, Y. 2014. Implementasi ASEAN free trade agreement terkait kinerja perdagangan Indonesia: Pendekatan model gravitasi. Buletin Ilmiah Litbang Perdagangan Kementrian Perdagangan Vol.8 No.1.

Goldar, B., Aggarwal, dan S. Chand. 2004. Trade liberalization and price-cost margin in India industries. Indian Council for Research on International Economic Relations, Working Paper. No.130.

Jayanthakumaran, K. 2002. The impact of trade liberalisation on manufacturing sector performance in developing countries: a survey of the literature. 
University of Wollongong Department of Economics. Working Paper Series 2002.

Krugman, P. 1986. Industrial organization and international trade. National Bureau of Economics Research. Working Paper No.1957. Cambridge: National Bureau of Economic Research.

Kuncoro, M. 2010. Masalah Kebijakan dan Politik Ekonomika Pembangunan. Jakarta: Erlangga.

Kwoka, J. E., dan D. J. Ravenscraft. 1985. Cooperation vs rivalry: price-cost margins by line of business. Working Paper of Federal Trade Comission. Washington, DC: Bureau of Economics.

Lee, E. 2005. Trade liberalization and employment. DESA Working Paper. No.5.

Lipczynski, J., J. Wilson., dan J. Goddard. 2005. Industrial Organization Competition, Strategy, Policy ( $2^{\text {nd }}$ Edition). Harlow: Pearson Education.

Martin, S. 1994. Industrial Economics: Economics Analysis and Public Policy. New York: Macmillan.

Özcan, K. M., E. Voyvoda, dan E. Yeldan. 2000. On the patterns of trade liberalization, oligopolistic concentration and profitability: reflections from post-1980 Turkish manufacturing. Economic Research Forum. Available at http://www.erf.org.

Pangestu, M., dan T. Feridhanusetyawan. 2002. Indonesian Trade Liberalization: Estimating The Gains. Jakarta: CSIS.

Promfet, R. 1992 International trade policy with imperfect competition. Special Papers in International Economics. No.17 (August). International Finance Section Department of Economics Princeton University.

Widodo, T. 2005. Industrial organization: A case study of Indonesian manufacture. Jurnal Ekonomi dan Bisnis Indonesia. Vol.20 No.4: 351-367.

Widodo, T. 2008. The structure of protection in Indonesian manufacturing sector. ASEAN Economic Bulletin. Vol.25 No.2: 161-78.

Wooldridge, J. M. 2006. Introductory Econometrics A Modern Approach. ShouthWestern Cengage Learning.

World Bank. 1993. The East Asian miracle economic growth and public policy. World Bank Policy Research Report. Oxford: Oxford University Press.

World Bank. 2008. World Development Indicators. Washington, D.C.

WTO. International Trade and Market Access Data. WTO Statistic News. Available at http://www.WTO.org. 
Yalcin, C. 2000. Price-cost margins and trade liberalization in Turkish manufacturing industry: A panel data analysis.Working Paper Türkiye Cumhuriyet Merkez Bankasý Araptýrma Genel Müdürlüðü. Available at http://www.tcmb.gov.tr.

Yarbrough, V. B., dan R. M. Yarbrough. 2006. The World Economy Trade and Finance. Massachusetts: Thomson South Western.

Yoseva, D. 2009. Peranan pesaing asing dalam persaingan pada pasar industri manufaktur domestik. Jurnal Persaingan Usaha. Vol.1: 39-60.

Zanden, J. L. V., dan D. Marks. 2012. Ekonomi Indonesia 1800-2010 Antara Drama dan Keajaiban Pertumbuhan. Kompas: Jakarta. 